\title{
THE TESTAMENT UNDER ROMANIAN CIVIL LAW PROVISIONS
}

\section{M.M. TUDORASCU}

\section{Tudoraşcu Miruna Mihaela ${ }^{1}$}

Faculty of Law and Social Sciences

Department of Juridical and Administrative Sciences

University "1 Decembrie 1918” of Alba Iulia, Alba Iulia, Romania.

*Correspondence:M.M.TUDORASCU, Unirii St., No.15-17, Alba Iulia, Romania

E-mail: miruna762001@yahoo.com

\begin{abstract}
The normative dispositions that we will refer to in this paper, are found in The Romanian Civil Code, in the 4th Book, called "About Inheritances and Liberalities", 3rd Title, called "Liberalities", 3rd Chapter "The Testament", articles 10341099. It is a very important civil institution, usually used, when a person wants to prefer somebody to collect the inheritance, a part of the inheritance, or a specific good from his estate. By article 1034 from RCC [1] "the Testament is the unilateral, personal and revocable legal act, through which a person, named testator, will decide, using a legal form, about his estate and other wills, for the time he will not be alive anymore". In the doctrine we find different opinions in connection with the content of the will (testament), in connection with the juridical nature of it, or in connection with the form vices or with the fundamental vices impact over the validity of the testament. The discussions are very extensive, so this is one of the reasons that we took in consideration for realizing this scientific paper. We will present also different types of testaments that we have provisioned in Romania, how the testament is proved under the Romanian legislation and how it is interpreted.
\end{abstract}

KEY WORDS: TESTAMENT, TESTATOR, ESTATE, CIVIL CODE, LEGAL ACT.

\section{INTRODUCTION}

The normative dispositions that we will refer to are found in The Romanian Civil Code, in the 4th Book, called "About Inheritances and Liberalities", 3rd Title, called "Liberalities", 3rd Chapter "The Testament", articles 10341099. It is a very important civil institution, usually used, when a person wants to prefer somebody to collect the inheritance, a part of the inheritance, or a specific good from his estate.

By article 1034 from RCC[1] "the Testament is the unilateral, personal and revocable legal act, through which a person, named testator, will decide, using a legal form, about his estate and other wills, for the time he will not be alive anymore". In the doctrine we find different opinions in connection with the content of the will (testament), in connection with the juridical nature of it, or in connection with the form vices or with the fundamental vices impact over the validity of the testament.

\footnotetext{
${ }^{1}$ Beneficiary of the Project financed from Lucian Blaga University of Sibiu research grants LBUS-IRG-2016-02
} 


\section{WHICH ARE THE LEGAL CHARACTERS OF THE TESTAMENT?}

It is a legal act - a manifestation of will, made with the purpose of producing legal effects [2].

It is a unilateral legal act - so it is valid when one will is expressed, of the person who leaves the testament (the will), no matter of the recipient will.

It is a personal legal act - it cannot be concluded by representation or by the legal guardian consent.

It is a solemn legal act - can be concluded just in the legal forms provided by the law, under the sanction of absolute nullity.

It is a legal act for death cause (in Latin - mortis causa) - because the effects are produced only after the death of the testator (of the person who leaves the testament). The recipient (beneficiary) of the will has no rights during the testator life.

It is a revocable legal act (essentially) - the testator can revoke the testament in a freeway, anytime without the obligation of explaining the facts that determined him to revoke it.

\section{THE CONTENT OF THE TESTAMENT}

In the content of the testament we can have: legacies, which can be: universal legacies, with universal title legacies and with particular title legacies; there can be also facts in connection with disinheritance in the frame of the law; in the testament there is the possibility of nominating a testamentary executor; some obligations for the beneficiaries of the testament; revocation of an early testament; the ascendant division, which is the division made by the testator between his descendants, for the whole succession or just for a part of it.

In the testament we can also find the recognition of one child by his mother or by his father. Also, we can find provisions in connection with the funerals, by art. 80 Civil Code. There is also the possibility to name by testament a legal guardian for the testator's children or contrary, to refuse to one person to become a legal guardian (articles 113, 114 Civil Code).

The testator can agree or not agree by the will, that after his death, his organs to be donate. He can propose by the will that after his death a foundation should be made with a specific purpose.

These are just some examples of what a testament could contain, but there are more possibilities.

If we are talking about the consent, as an essential element of any juridical act, that represents the will of the author, also in testament case is the primordial element. Art. 1038, al. 1 and 2 Civil Code, corroborated with art. 1204-1224 Civil Code, are proving these affirmations.

So, the will of the testator must be free and with no vices for the legality of the testament. The lack of consent (unilateral will manifestation), in connection with the testament, is sanctioned with the absolute nullity. Motivation for this is: the consent is an essential element; if this element is missing the juridical act cannot exist.

In testament area, the testator consent has to be serious, free and expressed with real

knowledgeably. If the consent, when the testament is made, is flawed by error, deception or violence, the testament can be asked for being annulled. The most situations, in testament area, are the ones in connection with the error and violence. For this we apply the common (domestic) law rules. 
If we are talking about the deception in our specific area, this can bring to the annulment of the testament, even if, the deception ways haven't been made by the beneficiary of the testament and also unknown by him. The ways for it are the conspiracy and suggestion (maneuvers used for convincing the testator to make a generosity, which in other circumstances he wouldn't have done it).

What is the conspiracy? - That maneuver (fraudulently) used by a person, to win the trust of the testator and cheat his good will, to determine him to make a generosity for the cheater.

What is the suggestion? - That hidden way (tendentious, hidden) placed in the head of the testator, for convincing him to make a testament, which he wouldn't have made it by his own will. For example: slander launching about the relatives.

When we are talking about deception we have to analyze: if the used methods were really injured (with fraud) and the result is really the alteration of the testator will. The conspiracy and suggestion must have been direct and overwhelming for the injury of the testator will.

By the practice, we can take in consideration, the next type of situations: the testator sequestration, the correspondence interception, removal of friends or relatives, because of the slanders or insults, the influence abuse or authority abuse.

Another element of the testament is the object. The object of the testament has to be determined or at least determinable; also it has to be licit. The sanction for not being as we said is the absolute nullity.

The object of the testament is licit when it is possible in accordance with the law and it is not against to the public order and good behavior.

In this order, in connection with the elements of the testament we have to talk about the purpose of the testament - or the cause. The cause (the purpose) is, practically speaking, the motive that is conducting the testator to some specific content of the will (art. 1235 Civil Code).

For being valid, the cause has to fulfill the conditions provisioned by art. 1236 Civil Code: to exist, to be licit, and to be moral.

The cause is illicit when it is against the law and public order, it is immoral and against the good behavior.

The lack of the cause means relative nullity for the testament. The illicit cause or the immoral cause means the absolute nullity of the testament (art. 1238 Civil Code). The validity of the cause is appreciated at the moment of testament opening and it is analyzed separately for each legal issue of the complex testament.

The cause is false, when the purpose representation, is not in accordance with reality. For example, the testator is thinking that the beneficiary of the will is his son.

The cause is illicit when the wanted purpose is against the provision of the law. For example: an imperative legal provision is ignored.

The cause is immoral when it is against the good behavior.

The falsity of the cause, illicit character of the cause and the morality of the cause most be proved by the persons who are attacking the will. The illicit character is very easy to prove, but the falsity or the immorality is very hard to prove.

A special place is taken by the capacity in connection with the testament. 
The capacity is treated specially. The rules are about the testament but also about donations. The applicable principle is that any person can make and get "free gifts" (in our case important goods - called liberalities), but of course in accordance with the provisions of the law.

The capacity condition is taking into account at the same day when the testator is expressing his will (he also has to have capacity to make a testament). The condition of capacity to be the beneficiary of a will must be fulfilled on the succession opening date.

Note: the will made in the favor of some administrative territorial institution, with the task of building a hospital and giving after also the inheritance goods to the built hospital, it is a valid testament (even is the situation of a new juridical person who is not born yet). The person who gets the inheritance exists (the administrative territorial institution) who has civil capacity to the moment of the inheritance opening.

If we are analyzing the lack of the exercise civil capacity of the testator, we will invoke the provision of art. 988 Civil Code: The person, who has no exercise civil capacity or has a limited exercise civil capacity, cannot make a testament, with the exceptions provided by the law.

Under the sanction of the relative nullity, even after getting full exercise civil capacity, one person cannot dispose in the favor of his ex legal guardian or his legal representative, before these persons weren't discharged by the court in connection with the administration of the goods of the person (who is suppose to become the testator).

The exception for the mentioned situation is when the legal guardian or the legal representative is a relative.

We consider that the person who has no legal capacity or has a limited legal capacity cannot dispose of the goods thorough liberalities (testament or donation).

So, we need to underline some issues:

The minor cannot dispose through a testament, in any case - it is a protection measure;

One person cannot dispose in the favor of his ex legal guardian or his legal representative, before these persons weren't discharged by the court in connection with the administration of the goods of the person;

From the goods of the person who is under court order interdiction, the descendents can get their part just with the permission of the family council and with the authorization of the guardianship court.

\section{TYPES OF TESTAMENT}

From the beginning we have to precise that the testament forms have limitative character, so, the testator will can be expressed just in the frames of the law. So, as we said before, by art. 1034 Civil Code, the testament is a solemn act, so if this requirement is not fulfilled, we get in the situation of absolute nullity. This is an ad validitatem condition, so if it is nor respected, we do not have a valid legal act. The testamentary disposition it is a solemn act, but through this it is not necessary all the time the authentic form.

In Romanian Civil Code we find three types of testaments:

Ordinary wills (holographic or authentic) - article 1040 Civil Code;

Privileged wills - article 1047 Civil Code;

Sums and deposit valuable wills - article 1049 Civil Code. 
We find two form conditions for all the types of the wills: the written form and the interdiction of the mutual testament. For this, we want to precise that, nor the testator major force, or his physical impossibility cannot remove the written form exigence. The written form cannot be replaced with the recordings or other modern procedures. This thing, in Romanian legislation is motivated by the fact that can be hiding a lot of frauds.

Holographic testament - the etymological origin comes from the Greek language: holos-whole; grafo-to write. The legal provision is article 1041 Civil Code: "under the sanction of absolute nullity, the holographic testament has to be written, dated and signed by the testator hand".

So we observe, by the text of the law, that this type of testament must fulfill three cumulative conditions:

The whole text of the testament must be written by the hand of the testator;

The date of the legal act must also be written by the hand of the testator;

To be signed by the hand of the testator.

The lack of one of three conditions is making the holographic testament not valid, so the sanction will be the absolute nullity.

The advantages of the holographic testament are the followings: can be made by any person who can write; it is very cheap because there are not notary taxes; can be made by a testator anytime and anywhere, without to be needed a witness; the secret over the testament contend is absolute; can be easily revoked.

The disadvantages of the holographic testament are the followings: can be easy hide or destroyed after the testator death; can be rigged very easy in compare with other testament forms; the willing of the testator can be flawed by deception; it is very easy to be challenged; can contain provisions which are poor drafted, that can lead to a difficult interpretation.

There are some issues that we would like to present in connection with the signature. This has to permit the identification of the testator. There is no use the stamps, the seals, the fingerprints. The testament in this situation will be not valid. The signature does not have to have both the name and surname, it is necessary to be the one which is usually used by the testator.

In connection with the opening on the holographic testament, before its execution, this will be present publicly to be validated for non-changing. The opening of the testament and the state of the testament will be registered in a minute. In the end of the procedure, the original of the testament will be given to the heirs if there is a settlement in this case, otherwise the court will decide about it - article 954, 1042 Civil Code.

Authentic testament - the provisions for this type of testament are articles 1043-1046 Civil Code. The testament is authentic when it was logged by a public notary or by another person invested by the state [3], in accordance with the law. During the authentication, the testator can be assisted by one or two witnesses. The presence of the witnesses is not obligatory.

The advantages of the authentic testament are: the large access of the persons to this testamentary form, including the persons who cannot read or write or being in impossibility for writing; to challenge the authentic will is harder; to cheat in this testamentary area is 
harder; the authentic testament cannot be stolen, hidden, destroyed, because an exemplary of the testament is kept in the public notary office.

The disadvantages of the authentic testament are the followings: the expenses in connection with this are quite important; it is very easy to find the secrets from the testament.

In connection with the procedure for this type of testament, we precise that the testator has to present himself in front of a public notary, where he dictates the dispositions in connection with the will. The public notary is writing the testament. After he writes the testament the public notary will read the testament or he is giving to the testator to read it himself, fact that will be precise in the legal document. After the reading of the testament, the testator will declare that the content of the will is expressing his real wishes. After these procedures the testator will sign the document and also the public notary will sign it and legalize it. After that, the testament will be registered in the national notary register, which is kept in electronical regime (article 1046 Civil Code).

If there are some special situations [4], as: the testator cannot write, read, he is deaf, ha cannot speak, he is blind etc., these will be underlined in the legal act. In these situations the presence of two witnesses is obligatory.

The privileged testaments [5]- this category is provided in article 1047 Civil Code. We have some special situations as:

When there are some epidemics, disasters, wars or any other similar situations, the procedure will take place in front of a competent functionary of local civil authority.

The procedure will take place in front of a ship commander if the testator will be on a Romanian ship, and the situation is similar if the testator will be in a Romanian plane.

If the testator is a military and he cannot address to a public notary, he will be able to make a will in front of the military unit commander.

If the testator is hospitalized in a sanitary institution where a public notary has no access, he will be able to go in front of the manager or his replacement in order, to make a valid will.

For all the situations that we mentioned before, there is obligatory the presence of two witnesses.

The privileged testament has to be signed by the testator, the two witnesses and the person in charge by the case. If one of them will be in impossibility to sign it will be written in the document. This type of testament will be caduceus in 15 day from the date when the testator would have the possibility to make an ordinary type of testament (holographic or authentic).

We have a particular case, revealed by article 1048, al. 2 Civil Code - when the testator is recognizing a child, the caducity is not interfering, even if the rest of the will dispositions will become caduceus.

Sums and deposit valuable wills - the legal provision for this institution is in article 1049 Civil Code.

The specialized institutions cannot hand the sums or the deposits just after a Court Order, or based on the inheritance certificate. It is important to know that the credit institutions have the mission to communicate for instance the testament dispositions to the National Notary Testaments Register. 


\section{THE CONJUNCTIVE TESTAMENT}

This issue is tight by the will of the testators and regards a legal interdiction.

What do we have to know?

Under the sanction of absolute nullity of the will, two or more persons cannot dispose through the same will, one for the other one or for a third person - art. 1036 Civil Code. The "Law maker" (legislature) is granting in this manner, the personal, unilateral and revocable character of the testament. If this interdiction wouldn't exist, the testament would have a contractual character.

We would like to present some practical issues:

The spouses cannot make testament for each other using the same legal act, they have to make different testaments;

If on the same paper appear two testaments, with different contents, both are valid (but they have to be signed separately) - there has to be analyzed if it is an intellectual merger or just a material one;

It has no importance if on the legal act appears the beneficiary signature (in case of a liberality with a task). It is not considered acceptance. When the succession is opened, the beneficiary can let it go freely for the provision in the testament made in his behalf.

Historically speaking, in Callimachus Code and Caragea Code it was permitted. At the beginning of the Civil Code from 1864, were also admitted the viability of the legal acts fulfilled before.

\section{THE VOLUNTARY REVOCATION OF THE WILL.}

If we consider the definition of the will, we can mention that it is an unilateral legal act, essentially revocable. The revocation can be made in two ways, express way or tacit way.

The Law Maker (legislature) provided that the express voluntary revocation (art. 1051 Civil Code), cannot be fulfilled but exclusively by a notary legal act - authentic, no matter if we are talking about a partially or totally revocation, or by an ulterior testament.

The ulterior testament can be made in a different form, not just like the testament which is revoked - we can revoke an authentic testament through a holographic testament.

The verbal revocation cannot produce a legal effect. The authentic revocation will be as once written (noted) by the public notary, in the National Notary Register of the Testaments - which is kept in electronic format.

The tacit voluntary revocation is provided by the law, in art. 1052 Civil Code, that says: the testator can revoke the holographic testament by destroying it, tearing it or erasing it. The erase of one disposition of the holographic will by the testator, involves the revocation of that disposition. The modifications fulfilled by removal (erasing way) have to be signed by the testator.

Destroying, tearing and erasing of the holographic testament (will), known by the testator, also is conducting to the revocation of the will, but only with the condition that the testator to be able to remake the will. 
The ulterior testament is not revoking the anterior one just in the limits of the dispositions which are contrary or incompatible with it. The effects of revocation are not removed when there is caducity or revocability of the ulterior testament.

We would like to underline some issues:

The simple crinkle or siphon of the will, cannot be considered revocation;

The ulterior testament is not revoking the anterior one, just in the limits of the dispositions which are contrary or incompatible with it.

The effects of revocation are not removed when there is caducity or revocability of the ulterior testament.

The revocation disposition can be retracted expressly by authentic notary legal act or by will (art. 1053 Civil Code).

\section{CONCLUSIONS}

In connection with this institution that we debated, we consider that there has to be applied the rules from the interpretation of the contracts. So we have to identify first the real wish of the testator. The testamentary clause is interpreted for producing juridical effects, and not in the way that we have no effects. When there is a doubt, the interpretation will be in the favor of the legal heirs.

It is a very interesting legal institution in Romania, this is the reason we decide to debate on it. In the end, after the legal issues that are already presented, we would like to make a specification. There are not allowed to be done, in Romanian legislation, liberalities for death cause, just by two legal acts, the donations and the legacies, legal acts that are found in a testament.

The donation - is a contract, that settles that one part, called the donor, is giving (irrevocably) a good, or more goods, to another part, called the grantee.

The legate - is a testamentary disposition, through which, the testator is stipulating that one or more heirs, will benefit from the testator goods after his death.

The conclusion is: this juridical institution is a very important one, with a lot of issues that can be revealed. The testament can co-exist with the legal inheritance in Romanian legislation, but we can also have just testament, or just legal inheritance.

\section{REFERENCES}

[1] RCC - the Abbreviation for Romanian Civil Code.

[2] Simion Mihaela, Drept civil. Mosteniri, Seminar Book, Romania, 2014, pp 40-47;

[3] Maria Ureche, Autoritatile publice in dreptul statelor europene, Book, Romania, 2011, pp 147-152.

[4] Laura Cetean-Voiculescu, Dreptul familiei, Course and Seminar Book, Romania, 2012, pp 83-85.

[5] Adam Dragoi, Miruna Tudorascu, Dreptul asupra mostenirii. Explicatii teoretice si aspecte practice, Book, Romania, 2016, pp 92-93. 